\title{
RÓŻNICE KOMUNIKACJI NIEWERBALNEJ \\ W POLSCE I CHINACH
}

\begin{abstract}
Wstęp
Obecnie mamy do czynienia ze zwiększoną intensywnością kontaktów międzykulturowych - zarówno tych pośrednich, jak i bezpośrednich. Dzieje się to i w życiu zawodowym, i w życiu prywatnym. Częstotliwość tych kontaktów zrodziła potrzebę większego skupienia się nad badaniami komunikacji międzykulturowej. Komunikacja zawsze była jednym z najważniejszych elementów kultury. To dzięki niej przekazujemy i interpretujemy informacje dotyczące rzeczywistości społecznej jednostki. Sposób interpretacji komunikatów nie wszędzie jest taki sam. Brak wiedzy na temat tych znaczeń bardzo często powoduje niezrozumienie, a niekiedy wywołuje sytuacje konfliktowe.

Głównym tematem artykułu są różnice w komunikacji niewerbalnej w Polsce i Chinach. Nim jednak do tego przejdziemy, warto zwrócić uwagę na to, czym jest komunikacja niewerbalna i jak ja definiuje literatura przedmiotu.
\end{abstract}

\section{Geneza i znaczenie komunikacji niewerbalnej}

Komunikacją niewerbalną, znaczeniem poszczególnych gestów i mimiki interesowano się już w starożytnej Grecji. Miało to charakter ściśle pragmatyczny - komunikację za pomocą gestów wykorzystywano w teatrze i podczas publicznych wystąpień ${ }^{1}$. Po upadku kultur antycznych nie rozwijano zainteresowania zachowaniami niewerbalnymi. Dopiero w XVIII w. John Bulwer napisał pierwszą publikację na temat języka migowego osób głuchoniemych. Francuski neurolog, Duchenne de Boulogne, analizował grymasy człowieka, którego mięśnie twarzy drażniono prądem elektrycznym. Dzięki jego eksperymentom wiadomo, że podczas zwykłego uśmiechu pracują nie tylko mięśnie ust, ale także te wokół oczu i na tej podstawie można odróżnić uśmiech szczery od nienaturalnego ${ }^{2}$.

ORCID: 0000-0002-9660-1980, DOI: 10.4467/23538724GS.20.051.13491

1 B. Taras, O niewerbalnych środkach prezentacji retorycznej [w:] Retoryka dzৃis, red. R. Przybylska, W. Przyczyna, Kraków 2001, s. 427-436.

2 A. Załazińska, Niewerbalna struktura dialogu, Kraków 2006, s. 73-83. 
Zdecydowana większość definicji skupia się na tym, że komunikat niewerbalny to przekaz, który przebiega za pośrednictwem zmysłów i wykorzystuje ich naturalne właściwości. Na każdy przekaz niewerbalny składa się wszystko to, co umożliwia odbiór i przekazanie informacji tylko i wyłącznie za pomocą zmysłów³ ${ }^{3}$ Inne definicje zwracają uwage, że komunikacja niewerbalna to sposób, w jaki ludzie komunikują się bez słów. W tym wypadku wskaźniki niewerbalne obejmują mimikę, ton głosu, gesty, ruchy ciała oraz sam dotyk ${ }^{4}$.

W literaturze przedmiotu wyróżnia się pojęcie aktów komunikacji niewerbalnej ${ }^{5}$. W węższym znaczeniu komunikacja niewerbalna to przekazywanie informacji za pomoca dynamiki i statyki ciała ludzkiego. Komunikacja niewerbalna wykorzystuje możliwości ludzkiego ciała, aby przekazać dany komunikat. W ujęciu szerszym tego typu komunikację można klasyfikować jako wszystkie niezamierzone pozajęzykowe komunikaty. Jedna z najprostszych kwalifikacji komunikacji niewerbalnej przedstawił Randall P. Harrison. Podzielił ją na kilka typów komunikacji:

1) komunikacja proksemiczna - komunikaty sa przekazywane poprzez aranżowanie przestrzeni;

2) komunikacja kinezyjna - chcąc przekazać komunikat, operujemy głównie ruchem ciała, a w szczególności kończyn;

3) komunikacja pozajęzykowa/paralingwistyczna - obejmuje ton, siłę głosu, rytm mówienia, intonację i akcentowanie ${ }^{6}$.

\section{Styl w komunikacji niewerbalnej}

Omawiając różne definicje komunikacji niewerbalnej w literaturze przedmiotu, nie sposób nie wspomnieć o pojęciu stylu komunikacyjnego. Biorąc pod uwagę główny temat artykułu, można stwierdzić, że w każdej kulturze ten styl będzie wyglądał i przejawiał się w inny sposób. Styl komunikacji definiuje się jako sposób ukształtowania tekstu w ramach tej samej zawartości komunikacyjnej, w zależności od wyboru konkretnych środków synonimicznych, które należą do danej odmiany języka ${ }^{7}$.

Obecnie obserwuje się odchodzenie od powyższego podejścia tradycyjnego na rzecz ujęcia holistycznego, które definiuje styl komunikacyjny w kategoriach ściśle semiotycznych, wykraczających poza ramy wyłącznie werbalnych zachowań komunikacyjnych ${ }^{8}$. Takie podejście uzasadnia posługiwanie się terminem „styl

3 W. Domachowski, Psychologia społeczna komunikacji niewerbalnej, Toruń 1993, s. 29.

4 E. Aronson, T.D. Wilson, R.M. Akert, Psychologia społeczna, Poznań 1994, s. 173.

5 J. Antas, Co mónia rece. Wprowadzenie do komunikacii niewerbalnej [w:] Retoryka dziś..., s. 437-460.

6 Podaję za: M. Brocki, Jesyle ciała w ujeciu antropologičnym, Wrocław 2001, s. 74.

7 K. Polański, Encyklopedia jezyykoznawstwa ogólnego, Warszawa 1999, s. 567.

8 A. Kudra, Idiolektostylem w mur, czyli o idiolekcie, idiostylu i krytycznej analizie dyskursu - na prayketadzie felietonów Krayssztofa Skiby w tygodniku „Wprost”, „Acta Universitatis Lodzensis. Folia Litteraria Polonica" 2011, t. 14, nr 1, s. 27-34. 
komunikacji”" również w odniesieniu do zespołu środków niewerbalnych jako elementów systemu komunikacyjnego.

Przestrzeń komunikacji niewerbalnej jest wypełniona przez idealnie z sobą skoordynowane komponenty stylu komunikacyjnego. W ich skład wchodza:

1) elementy kinezyki, tj. ruchy ciała, gesty. Największym problemem w ich zrozumieniu jest wysoki stopień uniwersalności tych znaków, jednak ich arbitralny charakter powoduje niekiedy różnice w nadawaniu im znaczeń. Dobrym przykładem jest tutaj pukanie się w skroń, co w jednej kulturze znaczy, że człowiek jest głupi (np. w Niemczech, Polsce, Francji), a w innej kulturze (np. Hiszpanii, Wielkiej Brytanii) wręcz przeciwnie - że ktoś jest mądry';

2) elementy mimiki i okulestyki odnoszą się do ekspresji twarzy. Niektóre kultury pod tym względem są zdecydowanie bardziej mimiczne od drugich. W kulturze Zachodu jest czymś normalnym, że chcemy nawiązać kontakt wzrokowy z naszym rozmówca. Jest to kulturowo akceptowane. Natomiast w kulturze Wschodu jest to postrzegane jako całkowity brak szacunku, ogranicza się także ekspresję twarzy do niezbędnego minimum ${ }^{10}$;

3) elementy proksemiki - w tym wypadku normy regulujące przekazanie komunikatu skupiają się na odległościach między rozmówcami. Najbardziej znana i jednocześnie klasyczna klasyfikacja przestrzeni między rozmówcami została opracowana przez Edwarda Twitchella Halla i obejmuje cztery strefy komunikacyjne: wewnętrzna i zewnętrzna strefa intymna (do $45 \mathrm{~cm}$ dystansu), osobista (45 $\mathrm{cm}-1,2 \mathrm{~m})$, społeczna $(1,2 \mathrm{metra}-3,6 \mathrm{~m})$ i publiczna (powyżej 3,6 m). Te normy mają oczywiście zmienny charakter i są dostosowane do okoliczności. W każdej kulturze dystans społeczny jest ujmowany w inny sposób - w kulturach Dalekiego Wschodu dystanse ulegają skróceniu ${ }^{11}$;

4) elementy haptyki regulują zasady przyzwolenia na dotyk, jego długość, intensywność oraz częstotliwość. W każdej kulturze przyzwolenie na dotyk jest inaczej regulowane, w zależności od złożoności związku interpersonalnego łączącego rozmówców;

5) elementy chronemiki wiążą się z punktualnością, czasem oczekiwania oraz czasem trwania spotkania. Są one bardzo ważne w spotkaniach biznesowych. Bardzo często na tym tle pojawiaja się nieporozumienia. Kultury monochroniczne, takie jak m.in. Japonia, przywiązują bardzo dużą wagę do czasu i punktualności kontrahentów. Terminy w przypadku współpracy z przedstawicielami tej kultury powinny być nieprzekraczalne. Z kolei kultury polichroniczne, takie jak m.in. kraje arabskie czy latynoamerykańskie, zwracaja zdecydowanie mniejszą uwagę na punktualność;

9 R.G. Gesteland, Różnice kulturowe a zachowania w biznesie, Warszawa 2000, s. 84.

10 D.G. Leathers, Komunikacja niewerbalna. Zasady i zastosowania, tłum. M. Trzcińska, Warszawa 2007, s. 53.

11 E. Hall, Bezgtośny jezylk, Warszawa 1987, s. 213-214. 
6) elementy paralangue sa kształtowane przez komponenty parawerbalne dźwięki, intonację, barwę, zasięg głosu, ton wypowiedzi. Głośne mówienie jest mile widziane w krajach Bliskiego Wschodu albo w krajach basenu Morza Śródziemnego ${ }^{12}$.

\section{Kultura Chin versus kultura Polski}

W dzisiejszym świecie współpraca i kontakty międzykulturowe stały się codziennością. Coraz więcej firm podejmuje współpracę z Chińczykami, wiele firm chińskich otworzyło swoje oddziały w Polsce. Obecność chińskich pracowników stwarza okazję nie tylko do wymiany doświadczeń gospodarczych, ale także do bliższego zapoznania się z tą kulturą.

Najważniejszym filarem kultury chińskiej jest zasada twarzy. „U źródła tej prostej zasady leży moralność, która nie kieruje się Dekalogiem, ale konfucjańskim systemem filozoficzno-społecznym, gdzie prawo i pięć zależności międzyludzkich, sformułowanych w neokonfucjanizmie, mają regulować działanie społeczeństwa"13. Utrata twarzy/ utrata reputacji często „prowadzi do głośnych samobójstw polityków, jak choćby prezydenta Korei Południowej Roh Moo-hyuna, który w 2009 r. rzucił się ze skały, po tym jak afera korupcyjna zawładnęła mediami. Podobnie było w przypadku szefa Hyundaia Chung Mon-huna, który w 2003 r. rzucił się z dwunastego piętra siedziby firmy w Seulu, po tym gdy wyszło na jaw, że zgodził się przelać na konto rządu Korei Północnej 100 mln dolarów, by pomóc ówczesnemu prezydentowi Kim Dae-jungowi w doprowadzeniu do szczytu Północ - Południe w 2000 r., za co tamten, o przewrotności losów, dostał Nagrodę Nobla"14.

Natomiast kultura polska opiera się na zasadach kultury honoru. Jej korzenie sięgaja judeochrześcijańskiego dziedzictwa Europy. W kulturze tej uczciwość oraz szczęście rodzinne sa postrzegane jako najważniejsze wartości. Zasada honoru w przeciwieństwie do chińskiej zasady twarzy obliguje do obrony własnej godności przed zniewagą pod groźbą utraty reputacji społecznej ${ }^{15}$.

Chińska Republika Ludowa to największe pod względem terytorialnym państwo Azji. Chiny to państwo unitarne, a ich terytorium dzieli się na 22 prowincje, 5 autonomicznych regionów i 4 miasta wydzielone, w których skład wchodzą Pekin, Chongqing, Szanghaj i Tianjin. Ponadto Chiny obejmują także 2 niezależne regiony

12 B. Nogalski, P. Jarocki, Komunikacja niewerbalna w negocjacjach miedsynarodowych, Bydgoszcz 1998, s. 55.

13 K. Dygulska-Jamro, Kultura twaryy versus kultura sumienia, CSPA, 21.12.2013, www.polska-azja. pl/k-dygulska-jamro-kultura-twarzy-versus-kultura-sumienia/ (dostęp: 14.03.2021).

14 Ibidem.

15 A. Szmajke, P. Bakk, E. Adamus, Relikety kultury honoru w mentalności Polaków, „Czasopismo Psychologiczne" 2004, t. 10, nr 1, s. 7-21. 
administracyjne - Hongkong i Makao. Chiny są najludniejszym państwem świata w 2020 r. liczba mieszkańców wynosiła $1396550000 \mathrm{mln}^{16}$. Gospodarka chińska jest jedną z najszybciej rozwijajacych się gospodarek na świecie ${ }^{17}$.

Żeby jak najlepiej zrozumieć komunikację niewerbalną kultury chińskiej, trzeba zapoznać się z ideą harmonii, która jest bardzo bliska Chińczykom i ma duży wpływ na ich kulturę. W języku chińskim słowo harmonia składa się z dwóch znaków 和谐. Pierwszy z nich oznacza pokój, łagodność, delikatność. Drugi oznacza harmonizować, być ze sobą w zgodzie, dojść do porozumienia ${ }^{18}$. Najbardziej skorelowanym z ową harmonią symbolem jest symbol yin-yang 阴阳, który pokazuje dwie przeciwności, uzupełniające się nawzajem, przeobrażające się w żeńską i męską siłę natury. Yin jest postrzegane jako mroczna, zimna i pasywna siła, natomiast yang wiaże się z aktywnościa, twórczościa, ciepłem. Harmonijne dopełnienie tych dwóch sił stanowi pięć żywiołów: ziemia, drewno, metal, ogień i woda.

W chińskiej kulturze harmonia odnosi się przede wszystkim do relacji międzyludzkich/społecznych. Chińczycy uważają, że harmonia jest zaletą człowieka, dąży się tutaj do harmonijnego współżycia człowieka z człowiekiem i człowieka z natura. Ludzie powinni żyć razem w harmonii i dobrze się dogadywać, co odnosi się zarówno do bliskich relacji, jak i do całego społeczeństwa ${ }^{19}$. Chińczycy uważają również, że harmonia przynosi bogactwo, a to z kolei odnosi się do relacji biznesowych.

Harmonia dotyczy całości życia chińskiego społeczeństwa - relacje między członkami rodziny są ściśle określone, przekładają się na wiele nakazów i zakazów, które wypełniane tworzą właśni harmonię w środowisku rodzinnym. Chińczycy wychodzą z założenia, że jeżeli harmonia w małych grupach społecznych, takich jak rodzina, jest osiagnięta, to przekłada się to na dalsze relacje społeczne zwiazzane $z$ władza $a^{20}$. Jako cnoty postrzegane sa powściagliwość i cierpliwość oraz odpowiedzialne podejście do wykonywanych obowiązków. Dotyczy to zarówno życia prywatnego, jak i zawodowego. W społeczeństwie chińskim bardzo mocno ceni się odpowiedzialność za rodzinę, umiejętność ciężkiej pracy i poświęcenia dla dobra ogółu. Ważny jest kolektywizm i umiar we wszystkim. Te wszystkie czynniki mocno wpływają na komunikację niewerbalna przedstawicieli chińskiej kultury ${ }^{21}$.

Jednym z przykładowych zachowań niewerbalnych w relacjach z obcokrajowcami, a mających głębokie powiązanie $z$ ideą harmonii jest intensywne przyglądanie się inaczej wyglądającym obcokrajowcom. W dużych miastach bardzo częstą reakcją

16 www.populationof.net/pl/china/ (dostęp: 16.03.2021).

17 G. Rosa, I. Ostrowska, K. Słupińska, L. Gracz, Komunikacja miężykulturowa w biznesie, Kraków 2018, s. 163.

18 W. Eberhard, Symbole chinskie, Kraków 2001, s. 313.

19 K. Mazur-Kajta, Harmonia w komunikacji o chinskim charakterze - spostrzeżenia z.polskiej (europejskiej) perspektywy, „Zeszyty Naukowe Politechniki Śląskiej” 2018, z. 124, s. 60-63.

20 J. Liu, Wprowadzenie do filozofii chinskeiej, Kraków 2010, s. 18-19.

21 G. Rosa, I. Ostrowska, K. Słupińska, L. Gracz, Komunikacja międsykulturowa..., s. 165. 
na widok Europejczyka jest intensywne zwracanie na niego uwagi. Dochodzi nawet do sytuacji, że miejscowi przerywają wykonywaną czynność, czasami nawet robią zdjęcia. Bywa, że w miejscowościach turystycznych obcokrajowcy zwracają większą uwagę niż zabytki. Co ciekawe, kiedy Chińczycy przebywaja za granica, nie zachowują się już w ten sposób. Ma to związek z zaburzeniem harmonii. W Chinach człowiek, który się wyróżnia, nie pasuje do reszty i w pewien sposób psuje harmonię. Za granicą naturalne jest to, że otaczają nas obcokrajowcy, natomiast gdy pojedziemy do Chin, będziemy traktowani jak ktoś wyjątkowy ${ }^{22}$.

\section{Międzykulturowe znaczenie dotyku}

Wiele nieporozumień, zwłaszcza na gruncie biznesowym, wynika z nieznajomości elementów haptyki. W krajach latynoskich, rejonu śródziemnomorskiego ludzie nie maja problemu z bliskością i poufałością. Polska również należy do krajów, w których dotyk jest powszechny. Uściski, pocałunki podczas spotkań z rodziną i znajomymi to norma. Chińczycy jednak nie lubia, gdy dotyka ich ktoś nieznajomy. Odnosi się to w szczególności do osób starszych oraz zajmujących wyższe stanowiska. W kontakcie z przedstawicielem tej kultury najlepiej poczekać, aż to miejscowi pierwsi zainicjują ten gest. W Polsce zdarza się też uścisk ręki za pomocą obydwu dłoni, co nie jest spotykane w kulturze chińskiej ${ }^{23}$. Polacy - w przeciwieństwie do Chińczyków - okazują sobie uczucia publicznie, trzymając się za ręce czy wymieniając pocałunki. Warto pamiętać, że w Chinach zasady i nakazy regulują niemal każdy aspekt życia, co także wpływa na zachowanie ich przedstawicieli. W Chinach udział w demonstracjach czy rozdawanie ulotek są zabronione. Przebywanie w stanie nietrzeźwym na ulicy, w miejscu publicznym, stanowi wykroczenie, czego nie można powiedzieć o Polsce.

\section{Poczucie czasu}

W komunikacji biznesowej z Chińczykami najbardziej uwidoczniają się kwestie chronemiczne. Współpracę można usprawnić, jeśli zrozumiemy odmienne poczucie czasu Chińczyków i ich podejście do planowania, terminów i przyszłości. Polska i Chiny różnią się znacząco pod tym względem. Polacy nie przykładają tak dużej wagi do planowania w długiej perspektywie czasowej. Kultura chińska natomiast na tym wyrosła, co wywodzi się z długofalowego planowania upraw. Chińczycy są zawsze zorientowani na długofalową współpracę i jednorazowe korzyści nie są dla

22 K. Mazur-Kajta, Harmonia w komunikacji..., s. 70.

23 E. Kuhnke, Mowa ciała dla bystrzaków, Gliwice 2016, s. 253. 
nich żadnym celem ${ }^{24}$. Zachodni partnerzy mogą więc odczuwać frustrację, widząc, jakie jest chińskie podejście do terminów. Ponadto mieszkańcy Państwa Środka mają wewnętrzna potrzebę negocjowania wielu spraw w tym samym czasie.

Istnieją także inne ceremoniały, które moga zaburzać życie biznesowe. W Chinach godzina 12.00 to pora lunchu, dlatego mile widziane, a nawet oczekiwane jest, by o tej godzinie rozmowy biznesowe toczyły się w restauracji. Omawianie biznesu podczas lunchu może się także przyczynić do lepszego poznania partnera, zacieśnić relacje osobiste. Chińczycy bardzo dbają o jakość relacji zgodnie z ideą harmonii.

W komunikacji międzykulturowej rozróżnia się kraje wysokiego i niskiego kontekstu wypowiedzi ${ }^{25}$. Kultury niskiego kontekstu są bardziej bezpośrednie, umieszcza się znaczenia w słowach, ważna jest zwięzłość komunikatu i wzajemna szczerość. W takich kulturach, mówiąc kolokwialnie, „nazywa się rzeczy po imieniu”. Chiny są kulturą o wysokim kontekście - tam bardzo istotna jest komunikacja niebezpośrednia, ponieważ znaczenie nadaje kontekst. Wzajemne komunikowanie nie wymaga zatem wielu słów, zdecydowanie ważniejsze są rytuały, ceremoniał i szacunek do partnera. W kulturach wysokiego kontekstu ekspresja niewerbalna działa zgodnie z zasada yizai yan wai (意在言外), czyli „prawdziwe znaczenie ukryte jest poza słowami”. Polacy plasują się kulturowo raczej w niskim kontekście, jesteśmy zdecydowanie bardziej ekspresyjni, mówimy wiele rzeczy wprost ${ }^{26}$. Jednym z większych problemów, zwłaszcza $\mathrm{w}$ aspekcie biznesowym, jest to, że Chińczycy unikają bezpośredniej odmowy. Dla Polaka może to być spore wyzwanie, zwłaszcza na gruncie zawodowym, gdzie ważna jest efektywna komunikacja. Jeśli pracownik w Polsce nie wie, co powinien zrobić, idzie do kierownika i pyta o dalsze wskazówki, a Chińczyk tego nie zrobi.

Kultury wysokiego kontekstu korelują z kolektywizmem, odznaczają się pojednawczym nastawieniem, nakierowanym na konformizm. Chińczycy nie wyrażaja więc uczuć wprost, nie formułują przekazów precyzyjnie. Bardzo dobrze pokazuje to jeden z przykładów przywołanych przez Katarzynę Mazur-Kajtę. Do dużego chińskiego przedsiębiorstwa został zaproszony profesor jednej z renomowanych uczelni. Jego wystąpienie miało trwać razem ze szkoleniem 2 godziny. Po 2 godzinach kolejny prelegent (obcokrajowiec) zaczął się niecierpliwić, że jego poprzednik nadal mówi. Obcokrajowiec poprosił pracownicę sekretariatu o interwencję. Sekretarka przeprosiła za sytuację, ale nie zdecydowała się zainterweniować. Wykład trwał jeszcze kolejne pół godziny, w międzyczasie obcokrajowiec wystosował jeszcze kilka próśb o interwencje, a wszystkie były nieudane. Obcokrajowiec nie mógł zrozumieć, dlaczego sekretarka nie zdecydowała się przerwać profesorowi

\footnotetext{
24 R. Pyffel, Bižnes w Chinach. Jak uniknqú problemów, Warszawa 2013, s. 16.

25 E. Hall, Bergtośny jezylk..., s. 215.

26 M. Budzanowska-Drzewiecka, A.S. Marcinkowski, A. Motyl-Adamczyk, Różnice kulturowe w komunikacji biænnesowej, Kraków 2016, s. 55.
} 
wystapienia, mimo że ją o to prosił wielokrotnie. Nie rozumiał także, dlaczego nikt z uczestników szkolenia nie zwrócił uwagi profesorowi, że przedłuża szkolenie. Ten przykład nawiązuje bezpośrednio do hierarchii i statusu w grupie. Profesor miał wysoki status, który bazował na jego wiedzy i wykształceniu. Sekretarka czuła, że jej pozycja jest niższa i nie chciała konfliktu. Nie chciała także urazić obcokrajowca, więc za którymś razem udała się do sali szkoleniowej. Gdy tam poszła, nie odzywała się, lecz pozwoliła, aby profesor dokończył wykład i nie zakończyła procesu komunikowania. Cisza i brak działań w chińskim społeczeństwie również jest działaniem - w ten sposób sekretarka okazała profesorowi szacunek. Tak samo postąpili uczestnicy szkolenia, którzy nie zwrócili profesorowi uwagi, że je przedłuża ${ }^{27}$.

\section{Znaczenie hierarchii, szacunku}

Na podstawie wyżej przywołanego przykładu widać wyraźnie, że w Chinach panuje bardzo wysoka hierarchiczność. Dystans władzy wskazuje na relacje między podwładnymi a przełożonymi i nie tylko. W każdej grupie społecznej obowiązuje hierarchia, nawet w stosunkach koleżeńskich czy w rodzinie. W Polsce nie mamy tak wysokiej hierarchiczności, powszechny jest pogląd, że nierówności powinny być zmniejszane, a sprawowanie władzy powinno być prawnie usankcjonowane. W krajach o wysokiej hierarchiczności dzieciom od najmłodszych lat wpaja się, że posłuszeństwo jest najważniejsze i dlatego Chińczycy w komunikacji często wolą nie powiedzieć nic, niż w ich mniemaniu okazać nieposłuszeństwo osobie o wyższym statusie społecznym. W społeczeństwach zrytualizowanych bardzo dużą wagę przywiązuje się do ubioru i odpowiedniego tytułowania. W Polsce to naturalne, że tak samo będziemy traktować gospodarza domu i panią od sprzątania. Nie odnosimy się do nich inaczej, nie okazujemy gospodarzowi domu większego respektu. W kulturach, w których ważny jest ceremoniał, niezważanie na okazanie szacunku może skończyć się zerwaniem relacji i powodować wiele negatywnych następstw ${ }^{28}$. Poziom ceremonialności w tym wypadku odnosi się nie tylko do kwestii zawodowych, ale także do takich czynników, jak płeć i wiek. W krajach, w których kobieta nie ma wysokiego statusu i rzadko osiaga wysoką pozycję zawodowa, bardzo nieufnie podchodzi się do prowadzenia interesów z kobietami, chyba że pochodzą z innej kultury.

27 K. Mazur-Kajta, Harmonia w komunikacji..., s. 70.

28 G. Hofstede, Kultury i organizacje. Zaprogramowanie umystu, tłum. M. Durska, Warszawa 2000, s. 58. 


\section{Etykieta zachowań w różnych kulturach}

Rozmawiając o komunikacji niewerbalnej w relacjach z Chinami, nie można nie wspomnieć o etykiecie. Wiele gestów jest tutaj nastawionych na zbudowanie harmonii, wymianę grzeczności, jak m.in. wspólne kolacje i prezenty. Wręczając prezent, trzeba pamiętać o kilku ważnych zasadach ${ }^{29}$. Chińczycy są bardzo przesądni, źle kojarzy im się liczba cztery, ponieważ brzmi podobnie jak słowo 'śmierć. Prezenty powinny być parzyste, co odzwierciedla filozofię przeciwieństw i równowagi. Bardzo duże znaczenie ma staranne zapakowanie prezentu, najlepiej w karton lub papier koloru żółtego, czerwonego lub różowego ${ }^{30}$. W kulturze chińskiej bardzo ważnym aspektem jest wdzięczność i budowanie harmonijnych relacji. Odwzajemnianie się prezentami za dobre relacje i przysługi stanowi codzienność w relacjach biznesowych w kulturze chińskiej i na pewno jest oczekiwane przez partnera, który współpracuje z Azjatami ${ }^{31}$.

\section{Dystans interpersonalny}

Nawiązując kontakty z inną kulturą, trzeba także pamiętać o elementach proksemicznych. Dystans fizyczny między ludźmi w wielu kulturach jest ściśle określony. W zależności od kręgu kulturowego ten obszar może być większy lub mniejszy. W Polsce dystans jest zdecydowanie mniejszy, naturalne są bliskie kontakty, okazywanie sobie życzliwości, obejmowanie się ramieniem. W ten sposób pokazujemy swoje życzliwe i przyjazne nastawienie, co dla przedstawicieli innych kultur może być oznaką zbytniej poufałości. W krajach azjatyckich dotyk jest ograniczany do niezbędnego minimum. W kontakcie z osobami z innego kręgu kulturowego najczęściej kontakt ogranicza się do podania ręki na przywitanie i pożegnanie. W kontaktach z przedstawicielem tej samej kultury rytuał pożegnań i powitań jest zdecydowanie bardziej skomplikowany i opiera się głównie na ukłonach. Nadmierne skracanie dystansu może obrazić druga stronę, niekiedy prowadzi także do zerwania stosunków biznesowych ${ }^{32}$.

\section{Ekspresja emocjonalna}

Elementy paralangue, związane z dźwiękiem, mogą być inaczej odbierane przez różne kręgi kulturowe. Włosi będący typowymi przedstawicielami krajów śródziem-

29 G. Rosa, I. Ostrowska, K. Słupińska, L. Gracz, Komunikacja międzykulturowa..., s. 167.

30 K. Karsznicki, Sztuka dyplomacji i negocjacji w śniecie wielokulturowym, Warszawa 2013, s. 112.

31 K. Mazurowska, Kulturowe i osobowościowe caynniki warunkujace harmonijne lub konfliktowe zachowania organizacyjne. Chincsycy i Europejcsycy w międzylkulturowym środowisku pracy, Warszawa 2011, s. 125.

32 G. Hofstede, Kultury i organizacje..., s. 54. 
nomorskich często wyrażają się głośniej niż inne nacje. Zdarzają się także sytuacje, w których bardzo podkreślają znaczenie swojej wypowiedzi, przerywają drugiej osobie. Polacy są zdecydowanie mniej głośni, natomiast w porównaniu do Chińczyków i tak mówimy za głośno i zbyt entuzjastycznie. W krajach azjatyckich milczenie jest odbierane jako oznaka szacunku i grzeczności. Ton głosu podczas rozmowy nie jest ekspresyjny, raczej cichy i spokojny. Kultura azjatycka jest zdecydowanie bardziej powściagliwa w okazywaniu emocji. Ogranicza się mimikę i ekspresję do niezbędnego minimum, intensywny kontakt wzrokowy między rozmawiającymi nie jest dobrze odbierany, a przerwa w rozmowie nie jest niekomfortowa, lecz stanowi normalny element konwersacji ${ }^{33}$.

Według filozofii chińskiej należy unikać skrajnych zachowań i dążyć do kompromisu zarówno w relacjach biznesowych, jak i prywatnych. Dlatego w sytuacjach spornych Chińczyk będzie dążył do koncyliacji, co jest jednocześnie domeną człowieka mądrego, bowiem mądry to taki, który potrafi uniknąć konfliktu. W kulturze chińskiej bardzo negatywnie jest postrzegany proces sądowy, uznaje się go za porażkę, co więcej, prowadzi on do wspomnianej już wyżej utraty twarzy. Chińczycy wolą uniknąć pewnych sytuacji niż doprowadzić do utraty twarzy, co może być frustrujące i niezrozumiałe dla przedstawicieli innych kultur ${ }^{34}$. Nie znaczy to jednak, że Chińczyka nie da się wprowadzić z równowagi. Jeśli do tego dojdzie, daje on upust swoim emocjom - wtedy przeklina i spluwa, nawet w miejscach publicznych.

\section{Chińska kultura relacji i gestów}

Budowanie reputacji jest dla Chińczyków sprawą najwyższej wagi. W Chinach podczas relacji biznesowych nikt się nigdzie nie spieszy, nie obowiązuje zasada czas to pieniądz, często wspominana w polskim biznesie ${ }^{35}$. Chińczycy uważają że wszystko ma swój czas. Bywa, że nie można dopiąć kontraktu, niby wszystko jest pozornie uzgodnione, ale chiński kontrahent twierdzi, iż jeszcze nie nadszedł właściwy moment, co wywołuje w zagranicznych partnerach frustrację. Oznacza to, że nie jest jeszcze gotowy na podjęcie ważnych decyzji.

W relacjach z Chińczykami ważne są też gesty. W Polsce gest kiwania głowa oznacza aprobatę, natomiast w Chinach nie oznacza wyrażenia poparcia czy zgody na to, co mówi partner, lecz stanowi jedynie wyraz tego, że druga osoba nas słucha, co jeszcze nie znaczy, że się z nami zgadza ${ }^{36}$.

\footnotetext{
33 B. Nogalski, P. Jarocki, Komunikacja niewerbalna..., s. 60.

34 G. Rosa, I. Ostrowska, K. Słupińska, L. Gracz, Komunikacja międry/kulturowa..., s. 166.

35 K. Karsznicki, Sqtuka dyplomacji..., s. 34.

36 M. Budzanowska-Drzewiecka, A.S. Marcinkowski, A. Motyl-Adamczyk, Różnice kulturowe..., s. 89 .
} 
Bardzo ważnym elementem kultury biznesowej są w Chinach wizytówki. Istnieją nawet specjalne rytuały związane z ich wręczaniem. Dzięki wizytówce Chińczycy orientują się, na jakim szczeblu w hierarchii jest dana osoba. W kulturze dalekowschodniej ma to bardzo duże znaczenie. Wizytówki z tekstem zwróconym ku rozmówcy wręcza się i przyjmuje oburącz, jednocześnie składając delikatny ukłon. Otrzymaną wizytówkę powinno się położyć na stole, a po spotkaniu schować do wizytownika. Dalekowschodni partnerzy poczują się bardzo urażeni, jeśli ich wizytówka zostanie włożona do kieszeni, co mogą odebrać jako zniewagę. W Polsce wizytówki nie mają aż tak dużego znaczenia - funkcjonują w relacjach biznesowych, natomiast nie wiążą się z nimi szczególne rytuały i ceremoniał ${ }^{37}$.

\section{Podsumowanie}

Chińczycy reprezentują kulturę mocno propartnerską, ceremonialną i hierarchiczną zarówno w zakresie biznesowym, jak i rodzinnym. Preferowany jest mało otwarty, oszczędny w gestach i słowach sposób wyrażania się. Podczas pierwszych kontaktów biznesowych należy zadbać o zbudowanie wzajemnego zaufania i dobrych relacji. Dla Chińczyków bardzo ważne jest życie w harmonii z innymi ludźmi, unikanie konfliktów i bezpośredniej konfrontacji, do której Polacy są przyzwyczajeni. Mieszkańcy Chin są zazwyczaj bardzo powściąliwi, mówią cicho, nigdy nie przerywają wypowiedzi drugiej osobie, zwłaszcza jeśli ma od nich wyższy status. Bardzo dobrze znoszą milczenie, nie wywołuje ono poczucia dyskomfortu, lecz stanowi wyraz okazania szacunku rozmówcy. W wielu sytuacjach biznesowych i rodzinnych bardzo ważnym aspektem jest ceremonialność, co także wiąże się z okazywaniem szacunku.

Hierarchiczność stanowi jedną z podstawowych zasad funkcjonowania społeczeństwa chińskiego, dlatego różnice w statusie społecznym są bardzo często podkreślane $^{38}$. To właśnie hierarchiczność powoduje, że Chińczyk milczy, mimo że nie do końca rozumie polecenie swojego szefa. Milczenie jest oznaką okazania szacunku osobie, która zajmuje wyższą pozycję społeczną. W związku z hierarchicznością młodzi ludzie i kobiety w chińskich przedsiębiorstwach mają mniejszy wpływ na negocjacje, ich zdanie często nie jest brane pod uwagę, ponieważ kultura chińska jest patrymonialna - kobiety bardzo rzadko osiagają wysoką pozycję społeczna. Młodzi ludzie są z kolei postrzegani jako zbyt mało doświadczeni, dlatego nie traktuje się ich z takim samym poważaniem w relacjach biznesowych.

W kontaktach personalnych Chińczycy, w przeciwieństwie do Polaków, bardzo oszczędnie gestykuluja, a niewiele wyrażają za pomocą mimiki twarzy. Zachowują także dużo większy dystans - przestrzeń personalna jest określana m.in. długością

37 Ibidem, s. 89.

38 K. Karsznicki, Sztuka dyplomacji..., s. 50. 
ręki. Polacy nie unikają dotyku, dla nas jest on naturalny i wynika z sympatii, natomiast Chińczyk bardzo nie lubi, kiedy dotyka go ktoś obcy. Wyjątkiem są sytuacje powitania i pożegnania, kiedy wystarczy uścisk dłoni. W relacjach biznesowych Chińczycy są bardzo ostrożni, na pewno na pierwszym spotkaniu nie podejmą żadnej decyzji, co ma ścisły związek z obawą o utratę twarzy.

W międzykulturowych kontaktach współpraca może okazać się szczególnie trudna ze względu na nieznajomość danej kultury, jej zasad i tego, co ją kształtuje. Normy, wartości, historia danego kraju mają bardzo duży wpływ na relacje biznesowe i pozabiznesowe. U osoby nawiązującej kontakt z przedstawicielem obcej kultury wzrasta poziom niepokoju i niepewności, co w konsekwencji może prowadzić do pewnych nieścisłości i trudności w komunikacji39. Bardzo często przeszkodą w zrozumieniu innej kultury jest swoisty etnocentryzm, uznawany przez wielu badaczy zjawiska komunikacji międzykulturowej za pierwotny stan umysłu, który uniemożliwia satysfakcjonujące funkcjonowanie w obszarze nowej rzeczywistości. Niezbędna w takich sytuacjach jest otwartość poznawcza i postawa zakładająca istnienie różnic kulturowych. Człowiek podchodzący w ten sposób do innych kultur nie będzie postrzegał obcej kultury przez pryzmat swojej, ale będzie próbował dostrzec rzeczywistość z punktu widzenia tej nowej kultury, którą poznał przed chwila. Wielu badaczy zjawiska komunikacji międzykulturowej wychodzi z założenia, że osiagnięcie postawy etnorelatywnej stanowi dla wielu ludzi wyzwanie, ponieważ wrażliwość kulturowa nie jest stanem naturalnym wśród ludzi, a przejście do tego stanu wymaga wysiłku i treningu.

Świadomość obcej kultury, jej niuansów, historii, norm i wartości może znacznie ułatwić współpracę, nie tylko na gruncie biznesowym. Warto jednak zaznaczyć, że to właśnie w działaniach biznesowych najczęściej widać brak zrozumienia i postawę etnocentryczną, która uniemożliwia pełne zrozumienie. Polski pracodawca, nieznający pojęcia dystansu władzy i hierarchiczności, nie zrozumie, dlaczego chińscy pracownicy niechętnie dyskutuja z decyzjami podjętymi przez przełożonych. Ich milczenie może być dla niego frustrujące, ale nie powinno ono dziwić osoby, która ma świadomość hierarchiczności, na jakiej opierają się społeczeństwa azjatyckie ${ }^{40}$.

Groźba utraty wizerunku, który dla Chińczyków jest bardzo ważny, skutkuje unikaniem sytuacji mogących wywołać zażenowanie. Omija się więc tematy problematyczne w obawie, że mogłyby prowadzić do sytuacji konfliktowych, których pracownicy chińscy również unikaja. Mając kontakt z Chińczykami, czy to na gruncie biznesowym, czy przyjacielskim, powinniśmy mieć świadomość powyższych zależności. Wymaga to niekiedy bardzo dużej wrażliwości na kontekst, na komunikaty wyrażane nie wprost. Zidentyfikowanie odpowiedniego kontekstu może znacznie

\footnotetext{
39 P. Boski, Kulturowe ramy zachowań społecznych. Podrecznik, psychologii miedzylkulturowej, Warszawa 2009, s. 566-573.

40 Ibidem, s. 570-573.
} 
przyśpieszyć i ulepszyć komunikację. Chińczycy mają bardzo silną potrzebę ujmowania całego życia społecznego w określone ramy zachowań, przepisów i praw, aby nie dopuścić do niepewności w życiu społecznym. Świadomość tego będzie ważnym krokiem do usprawnienia komunikacji, także tej niewerbalnej.

\section{SUMMARY}

\section{NON-VERBAL COMMUNICATION DIFFERENCES BETWEEN POLAND AND CHINA}

Polish and Chinese cultures were shaped in completely different geopolitical, social, and historical conditions. Non-verbal communication is closely related to cultural conditions. Chinese culture is based on the principle of face, and Polish culture is based on the principles of honour. However, it is very visible in the process of nonverbal communication, which directly influences the transmission and interpretation of information concerning the social reality of an individual. Additionally, the way messages are interpreted is not the same everywhere. You have to remember about the international filter in decoding the message. As a result, the lack of knowledge about these meanings very often causes misunderstanding and sometimes conflict situations. It should be emphasized that in the negotiation process one should know the cultural code, if we do not know it, misinterpretation may occur. For example, when on a pole, the nodding of a head in China may mean approval, but unfortunately the Chinese say that they are only listening to their opponent. These intercultural misunderstandings often result from intercultural egocentrism. The awareness of a foreign culture, its nuances, history, norms, and values can greatly facilitate cooperation, not only on a business or friendly basis.

To sum up, having contact with the Chinese, whether on a business or a friendly basis, we should be aware of the above dependencies. Sometimes it requires a very high sensitivity on the context of messages expressed indirectly. Identifying the right context can greatly speed up and improve communication. 